\title{
Teaching Method Used By Lecturer In Teaching English For Nursing Academy Program (A Study Of ESP)
}

\author{
Rangga Kusuma Admaja \\ STKIP PGRI Sidoarjo, email: ranggakusumaadmaja.rka@gmail.com \\ Sulistyaningsih \\ STKIP PGRI Sidoarjo, email: sulistyaningsih3112@gmail.com
}

\begin{abstract}
The background of this study is English Special Purpose, English Special Purpose has a specific term for each field. English has many functions in education or profession. English has many different purpose especially in Nurse Academy Program. Regarding to this case the teacher of English should be able to teach English for the students in Nursing Academy program with the appropriete teaching method. Based on the background of the study, the purpose of the study focuses to discribe the teaching method used by lecturer in nursing academy program and the responses' students in English in their field. The Techniques of collecting data in this research are observation, interview and questionnaire. This is a qualitative research design the writer describe the data briefly. The result of observation and interview showed that Spiral Teaching Method was the teaching method used by the lecture in teaching English of Nursing Academy Program, the method was appropriete with the concept of English special purpose. Whereas, the results of the questionnaire explain about the resposes of the students showed that the student's majority had a positive responses, it were showed that diagram were not presentage lower in $50 \%$ and the presentage was on $50 \%$ up to $100 \%$ in each item question. The conclusion in this research is the lecturer implements method used to teach English for special purpose in nursing academy program very well and the students gave respond positively in English in their field.
\end{abstract}

Keywords: English Special Purpose, Nursing Academy Program, Teaching

Method

\section{INTRODUCTION}

Generally, the Students study English "not because they are interested in the English Language or English culture as such, but because they need English for study or work purposes" (Robinson, 1991: 2). That is to say that English has Many kinds of a 
function where it can be used as several fields, such as: English as a basic lesson in elementary school, English as main lesson to produce the ability of speaking for junior and senior high school students, and also an English language will be needed by people who really need English for getting jobs, doing jobs, or as a tool for workers. The jobs that need English as a tool are flight attendent in airport, Enginers and Technician in a firm or it can also be used in medical fields. Despite of that English can be used for a specific purpose knowledge for those who needs English as their communication as language.

They need English as tool to explain their subject matter, according (Lamri, 2016: 3) "English Specific Purpose (ESP) is generally used to refer to the teaching of English for a clearly utilitarian purpose." Mackay and Mountford (1978: 2). Based of the state English should be taught to achieve specific language skills using real situations, in a manner that allows them to use English in their future profession, or to comprehend English discourse related to their area of Specificity.

Regarding to this case the teacher of English should be able to teach English for the student in Nursing Academy program with the appropriete teaching method. Here the teachers must have good ability in implemanting English Specific Purpose (ESP) because English has many functions in education or profession. English has many different purpose English Specific Purpose (ESP) eSpecificly in Nursing Academy Program. The student need Specific english in medical. Based on the background of the study above, the problem is stated: (1) What teaching method is used by the lecturer in teaching English of Nursing Academy program? (2) How are the students of Nursing Academy program responses toward English subject in their field?

The assumptions of this research are: The lecturer can implement method used to teach English for Specific purpose in Nursing Academy program and the students can respond positively in English teaching.

\section{REVIEW OF LITERATURE}

\section{English for Specific Purpose}

According Lamri $(2016 ; 5)$ ESP teaching approach is known to be learnercentred where learners need and goal are of supreme value, whereas General 
English approach is language-centred, and focuses on learning language from a broad perception covering all the language skills and thecultural aspects of the English speaking community. Robinson (1980:6) stated that "the general with which we are contrasting the specificis that of General education for life, culture and literature oriented language course in which the language it self is the subject matter and the purpose of the course".

\section{Characteristics of English Specific Purpose (ESP)}

English Specific Purpose (ESP) is Dudley-Evans and St. Johns tried (1998) to apply a series of characteristics, some absolute and some variable, to outline the major features of English Specific Purpose (ESP).

Absolute Characteristics:

1. English Specific Purpose (ESP) is defined to meet specific needs of the learners;

2. English Specific Purpose (ESP) makes use of underlying methodology and activities of the discipline it serves;

3. English Specific Purpose (ESP) is centred on the language (grammar, lexis, register), skills, discourse and genreappropriate to these activities.

Variable Characteristics:

1. English Specific Purpose (ESP) may be related to or designed for specific disciplines;

2. English Specific Purpose (ESP) may use, in specific teaching situations, a different methodology from that of General English;

3. English Specific Purpose (ESP) is likely to be designed for adult learners, either at a tertiary level institution or in a professional work situation. It could, however, be for learners at secondary school level;

4. English Specific Purpose (ESP) is generally designed for intermediate or advanced students. Most English Specific Purpose (ESP) courses assume some basic knowledge of the language systems, but it can be used with beginners. (Dudley-Evans \& St. John, 1998:4)

It is obvious that the absolute characteristics are specific to English Specific Purpose (ESP) because learner needs are of central importance when designing language activities. Concerning the variable features, English Specific Purpose (ESP) courses can be designed for a specific group using definite teaching methodology, nevertheless, all learners categories and disciplines can be concerned with English Specific Purpose (ESP). 
For that reason English Specific Purpose (ESP) should be seen simply as an 'approach' to teaching, or what Dudley-Evans and St. John illustrate as an 'attitude of mind'. Similarly, Hutchinson and waters (1987:19) stated that, "English Specific Purpose (ESP) should properly be seen not as any particular language product but as an approach to language teaching in which all decisions as to content and method are based on the learner's reason for learning".

\section{Definition of Teaching Method}

Teaching Method was the key of succes of the teacher in teaching process. It was the way that the teacher should do in order to provide an understanding of the students about the lessons. Method was very influential in teaching that shows value can be good or bad the teaching process. According Diah Fatmawati(2015:1) Method of teaching was one of the components that should be used in teaching to achieve the teaching target and improve students' abilities. Teaching Method principles conected with the progress of students abilitiy the appropiate teaching method can gave infuence the student to be more motivated in teaching process, can provide opportunities for expressing their ability, can allow students to learn solving problems, allow student to find discovery.

The methodologies of English Specific Purpose ( ESP ) teaching conform to the same model of the language teaching process as does any other form of language teaching. That is to say, the basic teaching activities are these; Shaping the input; Encouraging the learners intention to learn; Managing the learning strategies and Promoting practice and use. (Strevens, 1988: 44).

\section{Teaching Spiral Method}

Spiral teaching method is teaching method based on the premise that a student learns more about a subject each time the topic reviewed or encounttered. According supriyadi (2000: 06) "The spiral approach was an activity of presenting lesson material from easy materials an then more difficult and complicated, or the higher the concept the more widespread and deep", Afterward (Fahimeh and Fatemeh, 2011, 1117) Spiral learning teaching method is one of interactive teaching method consist of 11 steps.

1. Audio-visual

2. A teachers' question. 
3. A comprehensive response.

4. Grouping.

5. A teacher's questions and responses.

6. Mind Emancipation.

7. Writing what have been learnt.

8. Comprehensive study.

9. Revise and refiew notes.

10. A teacher conclusion.

11. A feel of satisfaction

\section{Definition of the respond}

According (jalalludin rahmat, 2005) respond has meaning as the result or memory that can be leaved from subject supervision, phenomenon, or another information that got with concluding the information and construe messages. Respond is an organim activity or moving in some activity that made from one stimulant. Afterward steven $\mathrm{M}$. Chaferespon (supporting Rahmat, 2005:218) devided respond into three part; Cognitive respond, Affective respond and Conative respond.

\section{RESEARCH METHOD}

The Research Method in this study used qualitative descriptive as the research design, the subject of the study was the English Lecturer and the students of Nursing Academy program in AKADEMI KEPERAWATAN KERTA CENDEKIA SIDOARJO 2017, The data collection in this study was the activities of lecturer and students activity during the teaching learning process about English and use -ing aproach English Specific Purpose (ESP) to study. The obtained data were described and explained descriptively.

Data collection were taken from instrument of field note observation, interview, and questionnaire. The procedure for the collection of the data were the first step, to write 
all description of teaching activities on the field notes. The writer described the situation which happened in the classroom during teaching learning process from the beginning until the end. The second step is interview to know teaching method which is used by the Lecturer in teaching English of Nursing Academy program.

The last step is questionnaire which proposed to find out the students respond toward English subject. The writer single out this procedure in order that he wanted to complete the collected data from each other to promote their validity and reliability.

\section{RESULT AND DISCUSSION}

Observation was conducted in three meetings of Nursing Academy Program KERTA CENDEKIA SIDOARJO, First meeting the writer described from the first time all the activities happened in learning proccess until the closing by the lecturer, the lecturer tried to remember about their assignment. They had tasks to read the book or literature about desease in their home and when they were in the classroom they explained what they read before. The lecturer made a small discussion in English used little instruction but sometimes if the students did not understand the lecturer would translate the instruction clearly, the lecturer taught the students with repeatation and drilling to make them understand the topic what they had learnt about the vocabullary, pronounciation, grammar that they had, the lecturer was dominate in the classroom to support the student with their comprehension what they learnt about Nursing Assessment.

The lecturer often repeated about what materials did the students before and it made them remember about it After that the lecturer stand in front of the class and start writing some keywords an instruction that was about the material. The lecturer draw a table on the left side and the table was on right side, the table's content with the point Nursing Assessment. The lecturer often repeated about what materials did the students before and it made them remember about it, The table was created by lecture that would be completed, the student could complete the table with their own opinion, the student had a chance to come forward in front of the class and completed the table. Second meeting the lecturer started the class by greeting made a situation friendly with her smile and attention with the student, the lecture asked the student's attendence list and checked them, the students were ready to receive the lesson after that the lecture asked the material 
that had been learnt by the student in the last meeting. The lecturer tried to remind about their own assignment, and asked the students to speak up, the lecturer would give a chance to the other student to share what they remembered.

The lecturer lead the students to make a small dialogue, the lecturer repeated more and more for the questions, drill one by one and the lecturer had a chance to corect the grammar and pronounciation of the students' with they own word if there were confused or forgot about the topic or did not know the material what they had wanted to speak up, the lecturer would give time to them to ask in their friends to solve the problem, The lecturer taught the student with repeatation and drilling to make them understand the topic that they had studied and to make clearly the vocabullary, pronounciation, grammar they had. The lecturer drew a table to fill by using the answer given, they are the definition, the causeds, the effect, the stage of the topic material, the sign and symptom and the treatment. the lecturer often repeated about the material that had explained before. The lecturer asked to the student to remind about it.

Third meeting, The lecturer gave the time for the students to prepare the material and the media used (LCD), The student presented the slide and explain to the audience. They presented their slide confidently showed what they knew about the "Diarhea", "treatment of Diarhea", "nursing assessment". That was all the material in the last meeting. After presentation there were three audiences who asked to the presenter. Sometimes the lecturer corrected their grammar, pronounciation and so on, they could disscuss with another friend to solve their problem, When the persentation was over the lecturer gave reviews what had they been doing so long, and she paid attention to the students, the lectuerer gave a feedback that made them better than before.

Students' responses toward English subject, In this part, the writer presented the finding from the students questionnaire. This questionnaire contented 10 questions. The instrument distributed to 24 student, there were 24 students in the class. the criteria of the student's answer, the writer analyzed the result of the questionnaire by using percentage. The finding are presented as follows : 
Table 1. The result of the questionnaire

\begin{tabular}{|c|c|c|c|}
\hline No & Pertanyaan & $\begin{array}{l}\mathrm{Ya} \\
(\%)\end{array}$ & $\begin{array}{c}\text { Tidak } \\
(\%)\end{array}$ \\
\hline 1 & Do you feel happy with the English lesson? & $100 \%$ & $0 \%$ \\
\hline 2 & Do you feel happy in learning English? & $91,66 \%$ & $8,33 \%$ \\
\hline 3 & $\begin{array}{l}\text { Does the lecturer created a teaching learning process } \\
\text { creatively and interest in the class room? }\end{array}$ & $54,16 \%$ & $45,83 \%$ \\
\hline 4 & Do the method appropriate with the students' need? & $79,16 \%$ & $20,83 \%$ \\
\hline 5 & $\begin{array}{l}\text { Does the lecturer use the teaching method active and } \\
\text { variative in teaching learning process? }\end{array}$ & $83,33 \%$ & $16,66 \%$ \\
\hline 6 & $\begin{array}{l}\text { Does the material English appropriate with the students' } \\
\text { need? }\end{array}$ & $91,66 \%$ & $8,33 \%$ \\
\hline 7 & $\begin{array}{l}\text { Do you give attention to the English subject matter } \\
\text { during teaching learning process? }\end{array}$ & $83,33 \%$ & $16,66 \%$ \\
\hline 8 & $\begin{array}{l}\text { Does the teacher's explanation in teaching English easy } \\
\text { to understand? }\end{array}$ & $62,5 \%$ & $37,5 \%$ \\
\hline 9 & Do you often get the trouble during learning English? & $79,16 \%$ & $20,83 \%$ \\
\hline 10 & $\begin{array}{l}\text { Does the Teacher often help and guide to solve the } \\
\text { problem during learning English? }\end{array}$ & $70,83 \%$ & $29,16 \%$ \\
\hline
\end{tabular}

Afterwards, the writer used a diagram to show the result of the questionnaire. It would be easy for the reader to read the result showed that the students' responses are positive. It could be seen from the diagram. The content showed that the student's majority had a positive responses, it were showed that were not presentage lower in $50 \%$ and the presentage was on $50 \%$ up to $100 \%$ in each item question. 


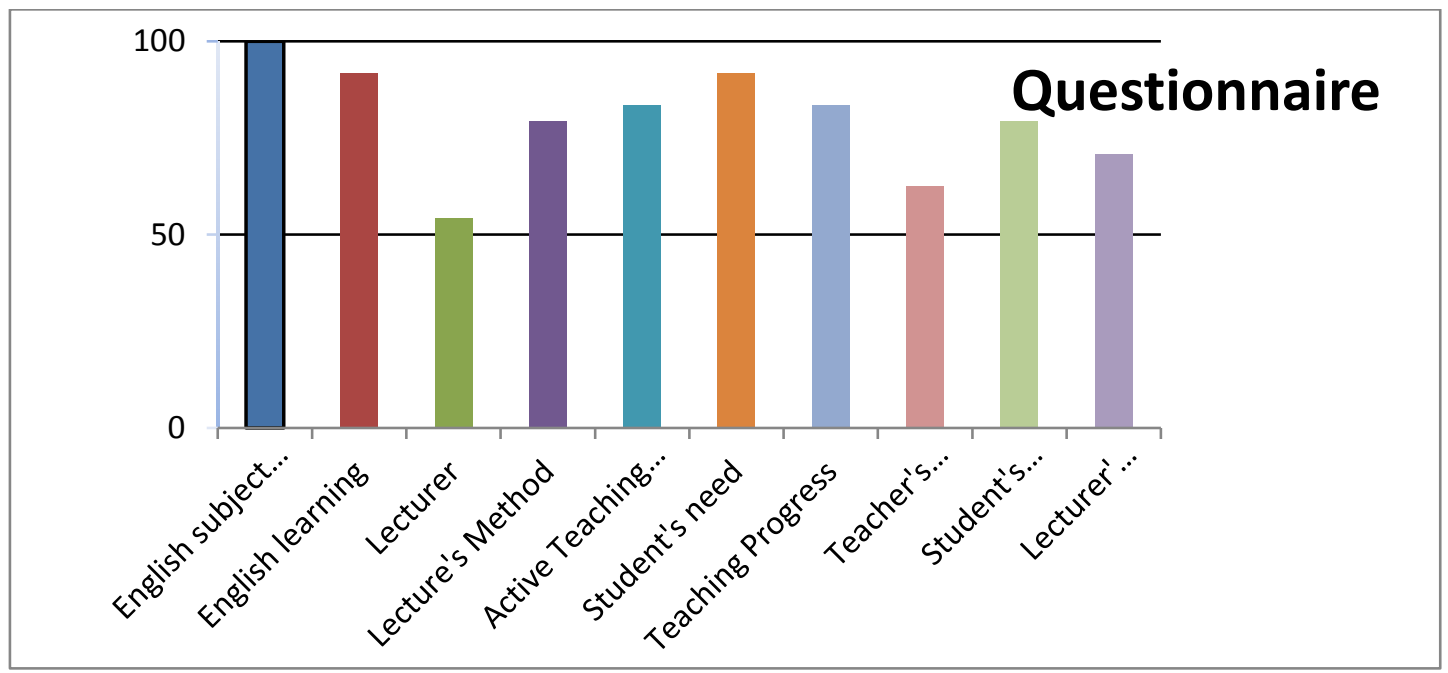

Figure 1. Results of Questionnaire

Based on the findings during third meeting, teaching learning process in the first meeting and the second meeting had the similarities, the lecturer taught the students with repeatation and drilling to make them understand the topic what they had learnt about the vocabullary, pronounciation, grammar that they had during teaching learnning process, the lecturer always showed the genaral content of the book and explain the English material what they needed from the general to specifict. The lecturer use draft or list to made the students know more about their material and remind the English subject was explained in the last meeting. Afterwards, it was found that it could obtained the teaching method used was Spiral teaching method, According supriyadi (2000: 06) "The spiral approach was an activity of presenting lesson material from easy materials an then more difficult and complicated, or the higher the concept the more widespread and deep", the lecturer was assumed about the teaching method which was used in nursing academy program was spiral teaching method that was belong part in English specific purpose (ESP) because her teaching method had goal focus in the students needs, the lecturer gave material from easy and complicated, it help them to made understand about English subject in their field. While, the third meeting had difference in teaching learning process. In this part the students had a task to present the material what they had in the last meeting. Generally the students study English "not because they are interested in the English Language or English culture as such, but because they need English for study or work purposes" (Robinson, 1991: 2). Based on the statement English had many purpose in the each field, the aimed of study English in Nursing Academy Program not only were 
understanding and knew the concept of Medical English but also they could express and communicate the concept in Medical English both written and spoken, the lecturer use presentation to know the students understand about the English subject so far and could express and communicate. Students' responses

The point of the questions related with the affective respond, According chaferespon,(supporting Rahmat, 2005:218) Affective respond is a respond that related with the emoticon, attitude or posture, assessing someone through something. Based on the findings in the third meeting using students' questionnaire. The writer found out that the student's had a positive responses. Majority of the students interested in the English subject matter, the student agreed that the lecturer used the strategy and teaching method variety active and appropriate with the students nursing accademy program needed. They felt helpfull by the teaching method, the lecturer created a interest teaching learning process in the classroom but sometimes the students still often nervous and had the difficulty in learning English, here the lecturer guidance were needed in teaching learning process, the lecturer had a great attention for her students in the class and the lecturer often help and conduct the solve the problem if they had a difficulty in study English had made the student felt very happy to study English. It was conducted by (Brown, 2000: 7), Teaching is an activity in which the teacher guides and facilitates learning, gives a chance for the learners to learn, and sets the condition for learning. In summary, the writer conluded based on the result of discussion, to answer the problem of the study :

What the teaching method was used by the lecture in teaching English of Nursing Academy program? Spiral Teaching Method was the teaching method used by the lecture in teaching English of Nursing Academy Program. And How was the students of Nursing Academy program responses toward English subject in their field? The students of Nursing Academy Program had positive respond English subject in their field.

\section{CONCLUSIONS}

Based on the result of discussion and data analysis on field notes and interview, it can be concluded that Spiral Teaching Method is used by the lecturer in teaching English of Nursing Academy Program, based on the result and data analysis on the questionnaires, 
most of the students answer positively, they are interested in the English subject matter, teaching strategy and Lecturer guidance.

\section{REFERENCES}

Brown, D. (2007). Principles of language learning and teaching. (Fifth edition). White Plains, NY: Pearson Education.

Dudley, E. and St Johns (1998) Developments in ESP a Multi-Disciplinary Approach. Cambridge: Cambridge University Press.

Fahimeh, Valedat. And Fatemeh Mohammadi. (2011). Spiral Learning Teaching Method : Stairr Steeped To Promote Learning. Tehran : Islamic Azad University Published Elsevier Ltd.

Fatmawati , D. (2015). The Implementation of using Direct Method on the daily Speaking ability at The second Grade MTS Plus Burhanul Hidayah Krembung. Sidoarjo : STKIP PGRI SIDOARJO.

Gatehouse, K. (2001) Key Issues in English for Specific Purposes (ESP): Curriculum Development . khoey [at] khae-service.com < http://www.khae-service.com>.

Johns, A. M. (1991). "English for specific purposes (ESP): Its history and contributions". In M. Celce-Murcia (Ed.), Teaching English as a second or foreign language. Boston: Heinle \& Heinle.

Lamri (2016) An Introduction To English For Specific Purpose (ESP). Tlemcen: Abou Bekr Belkaid University.

Mackay, R. and Mountford, A. (1978) English for Specific Purposes: A case Study Approach.London: Longman.

Robinson, P (1980) English for Specific Purposes.Oxford: Pergamon Press.

Strevens, P. (1977) New Orientations in the Teaching of English.Oxford: Oxford University Press.

Supriyadi, Udin Ganda dan Hanafi Natasasmita. (2000) Panduan Bahasa dan Sastra Indonesia. Bandung: Humaniora. 